\title{
The Economic Empowerment Through Entrepreneurship and Cooperatives for the Harmonization in Society
}

\author{
Adhi Iman Sulaiman ${ }^{1}$, Bambang Suswanto ${ }^{2}$, Masrukin $^{3} \&$ Rili Windiasih $^{3}$ \\ ${ }^{1}$ Department of Communication Science, Jenderal Soedirman University, Indonesia \\ ${ }^{2}$ Department of Political Science, Jenderal Soedirman University, Indonesia \\ ${ }^{3}$ Department of Sociology, Jenderal Soedirman University, Indonesia \\ Correspondence: Dr. Adhi Iman Sulaiman, Departement of Communication Science, Jl. Prof DR. HR Boenyamin \\ No.708, Purwokerto Sub-District, Banyumas Regency, Central Java Province. E-mail: adhi.2005unsoed@ \\ gmail.com
}

Received: September 3, 2019; Accepted: September 15, 2019; Published: September 17, 2019

The research is financed by Institute for Research and Community Service in University of Jenderal Soedirman and Ministry of Research, Technology and Higher Education of the Republic of Indonesia.

\begin{abstract}
The community has disharmony and potential conflicts caused by traumatic from terrorism arrests, so it requires anticipation in empowerment activities as a social and economic rehabilitation of the community. Therefore, the study aims to create economic empowerment models in entrepreneur and cooperative institutions for the harmonization of society. Study used qualitative research methods of Participatory Action Research (PAR). Data was collected through interviews, documentation, observation, and Focus Group Discussion. Informants have been purposive selected form each research location i.e. 25 people from the entrepreneurship group and cooperatives. Research location Binangun District of Cilacap Regency in Central Java and Cikoneng District of Ciamis Regency in West Java. The research analysis through triangulation, seeking diversity and investigation with society. The results showed the implementation of community economic empowerment model, it was succesful to set the spirit and togetherness to improve knowledge and skills of entrepreneurship and cooperatives, execute a program extension, training and comparative study. The successfully implemented to monitoring and evaluation in the form of assistance, expansion of market access and partnership, and then managed to become rehabilitation process of mental, social and economic from the traumatic, negative stigma and disharmony in the community after the event of arresing terrorism suspected.
\end{abstract}

Keywords: economic empowerment, entrepreneurship, harmonization, partnership, rural community

\section{Introduction}

The concept of village autonomy in village law is a manifestation of a participatory development concept embodied in the economic empowerment of the community into studies and programs that continue to be encouraged. Because the village is the foundation of development that determines the strength, progress and welfare of the nation, because the village is the closest government representation to the community, thus knowing the problems, potential, needs and prospects of the village community. Adi (2013) states that development in Indonesia will be less meaningful if there is no development in the village ommunity because there are still many villages that have not been developed optimally. Rangkuti (2011) states that the development paradigm is currently experiencing a shift where development emphasizes economic empowerment known as people centered development resource based development and institutional development.

Based on the spirit, support and seriousness of building the village, it is hoped that the village is not only the hometown that is loved and missed by its people outside the city or leaving the village, but the village can also be a friendly, comfortable, pleasant area and can ensure the welfare of its people, so it is not abandoned and ignored its builders. The latest paradigm emerged in 2013-2014, especially in Central Java Province, the development campaign on the concept of "Bali Deso, Bangun Deso" means returning to the village and building the village. Then in 2015 the term "Village Building" became "Building the village", meaning that the development acor is no longer dominant from people outside the village, but the villagers themselves who have the desire, initiative and 
work for the village to promote and prosper the village. The spirit and concepts of "Return to the village and building the village "are the concept of participatory development, people centered development and empowering community.

Community economic empowerment becomes the main concept and program in conducting village development in line with the challenges of reform, democratization and village autonomy. Village autonomy is realized with the enactment of Law Number 6 Year 2014 on the Village with its implementing regulations in Government Regulation Number 43. In Article 1 (8) Rural development is an effort to improve the quality of life and life for the greatest welfare of the village community. Article 78 (1) Village Development aims to improve the welfare of rural people and the quality of human life and poverty alleviation through the fulfillment of basic needs, the construction of village facilities and infrastructure, the development of local economic potential, and the sustainable use of natural resources and environment in paragraph (3) village development higlighs the spirit of togetherness, kinship and mutual cooperation to realize the mainstreaming of peace and social justice.

Based on a review of several research results that show problemsin village development especially in implementing economic empowerment among others (1) Villagers do not have the ability to create economic empowerment program. (2) The process of developing the economic empowerment program is still dominated by certain stakeholders such as village government and public figure actors as well as institutions that are closely related to the village government. (3) The role of women in the economic empowerment program development process is still limited with little involvement, limited access to information and opportunities. (4) Program and implementation of community economic empowerment is not comprehensive, sustainable, and tend to short term program, so that the community often get counseling and training, but less get assistance, monitoring and evaluation. (5) Implementation of economic empowerment is still partial and lack of synergy between economic empowerment actors such as government, private party, non-governmental organizations and universities, so that economic empowerment programs run independently and less mutually supportive. (6) Economic empowerment is less able to build and expand partnership and independence, so that society is still dependence, lack of institutional development, and product marketing. (7) Development in villages with substantial budgetary support from Village Fund Allocation and Village Funds is still oriented towards infrastructure development rather than community economic empowerment programs that can increase community motivation, capacity, institutions and economic welfare (Hubeis 2010; Harun \& Ardianto 2011; Handoko et al., 2014; Sulaiman et al., 2016a; Sulaiman et al., 2016b).

Based on the problemfrom several research results, this research have novelty that to design an economic empowerment program that can provide more open opportunity for the community in a participative, collaborative, and comprehensive manner starting from the planning of program formulation, implementation, report and evaluation. Society is no longer as the object of economic empowerment, but as the principal (subject) of development. Participatory planned and implemented economic empowerment need to consider the potential of villages from human, natural resources, economic resources and cultural resources that have become an integral part of promoting the village and prospering the village community. Potential community and village resources become the basis for planning and implementation of economic empowerment to be able to preserve and develop what has become uniqueness and strength of social capital of village community that is local wisdom.

As according to Vitasurya (2016) and Soegiono et al. (2019) that local organizations and wisdom, which grow and develop in society, need to be given wide space in order to be able to express and articulate various needs of society as self-supporting society and active role in development, especially for social welfare development. Likewise Mardikanto \& Soebiato (2012) explain that the economic empowerment of society as: (1) The process of change and require innovation in the form of ideas, products, methods, equipment and technology with the study and development of customs, values, traditions on indigenous technology. (2) The process to facilitate and encourage the community to become the main actors in utilizing its strategic environment to achieve sustainable development (long term). The strategic environment in question is the production, economic, social and ecological environment, as in the following figure. Christens (2012) asserts that participatory development requires economic empowerment that takes into account the psychological aspects of society such as the spirit, hope and recognition of the existence that must be achieved to develop community potential and participation. Azis (2017) explained the local wisdom can be formed from social valuesin the social structure of societyand has a function as a guideline, controller, and rules for behaving in various fields of life both whenconnect with others and withnatural environment. 
Community economic empowerment does not stop until it successes in improving motivation, ability, and productivity. It requires assistance to establish and expand partnerships. According to Popple and Quinney (2002) strategic objectives in the economic empowerment of local communities are developing effective partnerships and participating in institutions as learning through government support to engage in social engineering in communities with low economic levels. The concept of participatory development (participatory development) is a process that involves the community actively in all substantive decisions related to life. Mardikanto (2010) states that community economic empowerment is a participatory process that gives communities the confidence and opportunity to examine key development challenges and propose activities designed to address the issues faced dynamically, actual and potential based on regional, regional and national programs.

Based on this, the author is interested to conduct a study on the model of community economic empowerment in entrepreneurship and cooperative institutions located in the Al Muaddib Islamic Boarding School in Pasuruhan Village, Cilacap, Central Java and Nurussalam Islamic Boarding School in Kujang Village, Ciamis, West Java. The location is of concern to the national and international public after the arrest of terrorism in 2009-2012 which has an impact in the community, namely the existence of covert conflict, traumatic sense and harmonization of disturbed society. This study is the result of research the first stage from 2012 to 2015 starting from the discovery of problem identification and analysis and potential, economic empowerment program planning process, and second stage from 2017-2019 to implementation of economic empowerment such as counseling and training, establishment and development of community economic institution, assistance and expansion of marketing access and partnership.

\section{Method}

The research methods must be in accordance with the need to construct deeply the problems, potentials and solutions in the development of society, namely by participatory qualitative methods such as Participatory Action Research (PAR). PAR have involving active participation of stakeholders and jointly taking action to overcome or correct problems experienced based on critical historical, political, cultural, economic, geographic and other contexts (McIntyre, 2008); (Reason \& Bradbury, 2008).

Research location at Binangun District of Cilacap regency in Central Java and Cikoneng District of Ciamis regency in West Java. Data collection is taken by interview, direct observation, documentation and Focus Group Discussion, with the determination of research subject (informant) each research location through prurposive that is 25 people as community worker from entrepreneurship group and Cooperative group, practitioners and community economic empowerment economic empowerment.

Analysis of PAR data are: (1) Performing triangulation principle used either on method, source or discipline. (2) Seeking the diversity of both equations and differences. (3) Investigating directly from and with local communities (Adi, 2013)

\section{Results and Discussion}

The research process is carried out in 2017-2019 to conducting research and implementation of economic empowerment for entrepreneurship development and Village community cooperatives. The process stages of research has similarities that are important to assess the economic empowerment management as follows are: (1) introduction study by conducting literature review of academic research results, scientific journals, and mass media both print and electronic. (2) Opening access to research sites for research permition, introductions, approaches and observations, as well as conducting interviews and documentation. (3) Discussing the results of the literature study stage and opening access with research teams, practitioners, activists and community economic empowerment actors. Discussion results are able to identify and formulate problems, focus, objectives, research benefits and research methods used.

As in the community economic empowerment study process that initiates the introduction study phase, opening access and approaches to the community to build public support and openness with dialogue and openness about local social, economic and cultural conditions. So that community economic empowerment can be planned, made program and implemented based on identification and analysis of problem, potential and prospect in society both human resources, economic resources, environmental resources and socio-cultural resources.

\subsection{Community Economic Empowerment in Institutional Entrepreneurship and Cooperatives}

The results showed that the people of Pasuruhan Village, especially in the Al Muaddib Islamic Boarding School and Nurussalam Islamic Boarding School in Kujang Village have in common to felt traumatic with the three arrests of suspected terrorists, negative stigma and disharmony between people who avoided interacting with families related to the arrested. However, the mediation process supported and assisted by the village government 
through the dialogue by inviting the two sides, resulting in a mutual understanding and mutual agreement of shared hopes and desires to be able to shape and develop economic institutions according to potential and interest through community economic empowerment program. It requires a holding company in the form of a Cooperative that provides agricultural needs such as seeds, fertilizers and agricultural medicines and agricultural equipment. Then strengthening the entrepreneurship of micro business that has been running that are farmer group, livestock group of catfish and ducks, group of broom stick handicraft, and business group making of brick. Windiasih (2002) asserted that in the implementation of economic empowerment can also be done to the targeted community that has special characteristics as a marginalized and traumatic community by approaching, assisting and providing dialogue room to express the problem, potential and the expected economic empowerment program.

According to Ardiana et al. (2010) the development of human resource competencies of Small and Medium Enterprises (SMEs) must be considered, so as to create entrepreneurial workforce that can compete openly in the global market. Increased human resources Cooperative management is also indispensable for the development of SMEs in capital loans, facilitating business networks, procurement of raw materials and marketing of SME products. Nurbudiyani (2013) states entrepreneurship and cooperative management as a model to foster learning and entrepreneurship skills.

The outcomes of the workshop dialogue resulted in agreement of program plan, implementation, monitoring and evaluation of community economic empowerment for entrepreneurship and Cooperative development. The next stage is the consolidation of the economic empowerment program plan as a result of community agreement, which involves practitioners, activists or observers of community economic empowerment. This is a form of community economic empowerment management to design the planning, implementation, assistanceto, monitoring, and evaluation of economic empowerment programs in an integrated, sustainable and comprehensive manner based on mutual agreement of community consultation.

In the management of dialogue and participatory communication process economic empowerment in the workshop or deliberation becomes the determinant for the sustainability of activities, because the community must open to aspire, support and participate in economic empowerment activities. According to Tattersall (2015), Sahakian and Dunand (2014) that social economics and solidarity in society have the potential to become sustainable economies by participating in developing and managing communities based on collective agreements for the public good and enhancing the capacity of community leaders to implement collective decisions that unite society. Gruidla and Hustedde (2015) emphasized the importance of dialogic, participatory, representative and egalitarian dialogue as a fundamental goal in community development to make sound and fair decisions.

The next phase of community economic empowerment is the implementation of counseling and co-operative training on institutional cooperatives, management, administration, membership, capital, finance, and distribution of the remaining business results, as well as meeting mechanism. Finally can be formed cooperative management form and named Cooperative Abdimas Sejahtera in the Al Muaddib boarding school at Cilacap Regency, which provides agricultural needs such as seeds, fertilizer and pest control. Likewise, in the Nurussalam boarding school in Ciamis Regency a cooperative has been formed in the Insan Nuda mini market that provides basic needs, both cooperatives could be openly accessible to the public.

Cooperative management form as a pioneer team that initiated the implementation of financial administration and management invites community and entrepreneurship groups to become members and administrators. Then the next step is to schedule board meetings and members to choose a formal stewardship for a period. The formation of cooperatives is very compatible with the social, cultural and economic of rural communities that still have the nature of mutual cooperation, solidarity and awareness. Gemina et al. (2013) states that membership management and participation of members together or partially affect the benefits and competitiveness.

The next step is to strengthen the Cooperative Institution in addition to provide mentoring activities, also conduct comparative studies to cooperatives that have been advanced to improve motivation, inspiration and access network partnerships. Then it is necessary to conduct monitoring and evaluation through observation, non-formal dialogue and deliberation of the board and members of the Cooperative. Monitoring and Evaluation indicators are administrative completeness, financial records and reports, sales circulation, the amount of capital and profit assets, records and smoothness of the loan, then the amount, membership and membership administration, and the cooperative development plan. The result of monitoring and evaluation is that it is necessary to combine economic business groups as entrepreneurship that already exist in the community to become members, administrators and business units within the cooperative structure.

The evaluation of empowerment activities shows that Abdimas Sejahtera Cooperative and Insan Nusa have succeeded in becoming cooperatives with legal status so that they can work together specifically in obtaining bank 
capital loans, and government and private assistance, even though Insan Nusa Cooperative is a franchise from Shariah cooperative business partners in Tasikmalaya Regency. Khairunnisa et al. (2019) explains the importance of developing the institutional capacity of economic enterprises in the village with organizational management for capacity building, joint decision-making, leadership, and institutional facilities and infrastructure. Institutional strengthening management by strengthening institutional vision, enhancing entrepreneurship capability, and building institutional cooperation network. According to Christens (2012) economic empowerment process to support community development on local power management and community decision making. Likewise Pama and Ganesha (2014) state that strengthening institutional economic empowerment is intended to produce sustainability of natural resources and various efforts to sustain life development activities, hence the necessary rural economic institutions can provide power for farmers.

Strengthening and development of cooperatives and community entrepreneurship is carried out by opening access to local governments in this case the Department of Cooperatives and small and medium business groups, Food Security Service and Counseling for a dialogue about the results of research. Following the dialogue, the local government is willing to participate in the economic empowerment program that has been created and implemented by providing additional counseling, training and mentoring. Then succeeded in opening access and facilitating the Abdimas Sejahtera Cooperative to become a legal entity Cooperative, and received a public business credit program socialization from the Government Bank to assist entrepreneurial capital and cooperatives. While the Insan Nusa Cooperative independently partnerships by becoming a franchise business of the Tasikmalaya Regency sharia cooperative.

Pranoto and Yusuf (2014), Huda, et al. (2018), Hilman and Nimasari (2018), Rodiah et al. (2018) that economic empowerment program has a purpose to solve the impact of social problems, but it requires the role of all parties such as government through its policy, business world with Corporate Social Responsibility (CSR) and community organization with its activity.

According to Hasim and Remiswal (2009) the participative development is to implement: (1) empowering as an effort to realize the capability and independence of society, (2) transparency in every process and stages of planning, implementation and development control that can be accessed by all community, (3) The accountability of each development process can be well accounted for, (4) The development process must be sustainable, (5) Participation is active and involve the community in the development process

Next stage of community economic empowerment management is the formation and development of entrepreneurship that already exist in the community such as farmers, catfish and duck farmers, craftsmen broomsticks and brick makers. Their products have been purchased by the collectors and can be sold in Cilacap regional markets. However, entrepreneurship is still separated or not in the form of business group, has not got counseling and training in improving the quality and quantity of production.

Economic empowerment management for entrepreneurship begins by opening a dialogue forum involving entrepreneurs and cooperative management who exist in the village of Al Muaddib in Pasuruhan Village and Nurussalam in Kujang Village. The purpose of dialogue activities is to design and implement economic empowerment programs based on identification of problems that have been faced, to analyze the potential and prospect to improve the quality and quantity of products and the expansion of marketing networks. According to Sulistiono et al. (2018) economic empowerment is a continuous process of participation to develop knowledge, skills and competencies in overcoming problems and common needs, bringing about changes in people's lives, and can control the interests of collectively both social, economic and political. Nurcholis et al. (2009) state a model of development planning involving the community and all stakeholders known as participatory development planning. Communities actively involve themselves in identifying, formulating, and finding alternatives to problems.

Then prepare the agenda of solving and the process of discussion, implementation and evaluation. Similarly, according to Mikkelsen (2011) the local communities involve in the selection, design, planning, and implementation of the program with consideration of perceptions, patterns of attitudes, thought patterns and values and knowledge owned by the community then feedback from development activities.

The next stage of deliberation with entrepreneurs is to form groups according to the same field of business, the goal is to be able to support each other, cooperate, strengthen and develop business. Finally they can form three groups of businesses namely farming groups, business groups of craftsmen, and groups of farmers who are part of the Cooperative both as members and administrators. The three entrepreneurial groups are community development based on aspirations, potential, needs and agreement of village communities. As according to Riosa and Lachapelle (2015) community development is a commitment to equality in opinion and participation through a 
dialogue and fair deal. Wibowo (2014) describe the most effective and quickest way to empower villagers to achieve the objective is to involve communities and government elements that are "pro poor" with development policies that are more actively prioritizing the needs of rural communities.

Subsequent activities are conducting surveys and observations to community entrepreneurs to conduct assessment or analysis of the condition, situation, potential and business prospects. The results of deliberations, surveys and observations were reviewed with practitioners and economic empowerment activists to design planning, implementation, assistance, monitoring and evaluation of entrepreneurship economic empowerment practices. Implementation of economic empowerment begins by doing counseling and training to motivate, unify vision and mission. Then add knowledge and expertise in member management, more effective and efficient production process, packaging and product labeling, promotion strategy and marketing. The process of execution of counseling, training and assistance involves the local government in this case the department of agriculture, livestock and small business groups, then colleges and students.

The monitoring and evaluation phase of entrepreneurship processed with an informal approach through personal and group communication in each business group with the indicator of cooperation and cohesiveness, capital and profit, product quality and quantity, expansion of marketing network and activeness in Cooperative. The results of monitoring and evaluation of entrepreneurship recommend mentoring activities about fund recording, profit sharing and venture capital, capital increase and partnership with the Bank. So the next stage of economic empowerment management is to facilitate entrepreneurial groups to get socialization and access to business capital loans to the Bank.

\subsection{Designing Model of Economic Empowerment in Entrepreneurship and Cooperative Institutions}

Based on the implementation of community economic empowerment stage in entrepreneurship and cooperative institution of Al Muaddib Islamic Boarding School in Binangun District and Nurussalam Islamic Boarding School in Cikoneng District. The identificaion and analysis result can be made as a foundation in designing community economic empowerment model (Figure 1). The economic empowerment in entrepreneurship and cooperative institutionsamong them cooperatives economic empowerment, it have problems i.e.

- Cooperative has not yet legal

- The cooperative administration has not yet been executed as it records the members of the cooperative, the membership card has not been given yet

- Manual administration and financial statements are not equipped with computerized backup

- Welfare rights of cooperative management has not reached

- Institutional economic empowerment groups are still not solid and have not developed or are still passive

- Underdeveloped Promotion and Marketing,

- Unscheduled partnership access

- Entrepreneurial and management cadres are still lacking

- Leadership regeneration in business groups is still inhibited

- Increase the quantity of membership

Potential owned i.e.

- The board has high spirit and consistently wants to develop cooperatives

- There is an entrepreneurship group and a Cooperative as a group of economic empowerment

- Economic empowerment groups have followed the initial series of economic empowerment programs in the form of counseling and training.

- Potential communities become new members and managers in entrepreneurship and cooperative groups

- Cooperative Abdimas Sejahtera and Insan Nusa, farmer groups and other business groups have high interest and spirit to develop the business and follow the economic empowerment program

- There are the management of business groups and Sharia Cooperative Abdimas Sejahtera and Insan Nusa

- The type of business has been going on for quite a while and gets a clear market share

- Close to banking and economic centers such as the huge Kroya and Adipala markets as well as their strategic trading scale 
- Support from village Governments for strengthening and developing entrepreneurial and cooperative institutions

Analysis of program planning and implementation, i.e.

- Registering cooperatives to have permits and legal entities

- Control the administration of cooperatives both identity and membership card as well as financial manually and with computerization

- planning to grant welfare rights in the form of honorarium for cooperative management

- Reinforce the concept of a comprehensive community economic empowerment program (complete) to economic empowerment groups ranging from counseling, training, mentoring and partnership with participatory-dialogical methods

- Make regular meeting activities at least once every 3 months to discuss about the development of economic enterprises

- Conduct membership recruitment openly and socialized in the community to join the entrepreneurial group

- Create upgrading program or capacity building of entrepreneurship group and Cooperative group

- Conduct market survey for price, quantity and quality of product required

- Conducting comparative studies to other entrepreneurial groups

- Improve the quality and quantity of production to meet market needs

- Establish access to Banks that provide business capital loans

Monitoring results and evaluation, i.e.

- Successfully conducted training and mentoring about the managerial improvement of Cooperative management, membership administration and finance of Cooperative.

- Reactivate Board meetings and Cooperative membership and successfully become a registered cooperative and incorporated

- Have a concept for the welfare of Cooperative management

- Cooperative management, farmer groups and compact business groups conduct consultation/dialogue in developing institutions and their business

- Farmers groups and business groups agreed to become members of the Syariah Cooperative Abdimas Sejahtera and Insan Nusa

- Has facilitated the Cooperative and small and medium business groupsof Cilacap Regency by counseling, and mentoring to entrepreneurship groups and cooperatives

- The entrepreneurship group develops the business by successfully establishing credit access to the Bank and stop getting the capital from the loan shark

- The marketing of catfish group and broom have been growing very fast and they should increase their production because the market demands are very high

- The Bank has conducted counseling, approach and observation of the creditworthiness of the business loan that has finally given its trust and loan.

The economic empowerment matrix in entrepreneurship and cooperative institutions can then be made the model presented in Figure 1. 


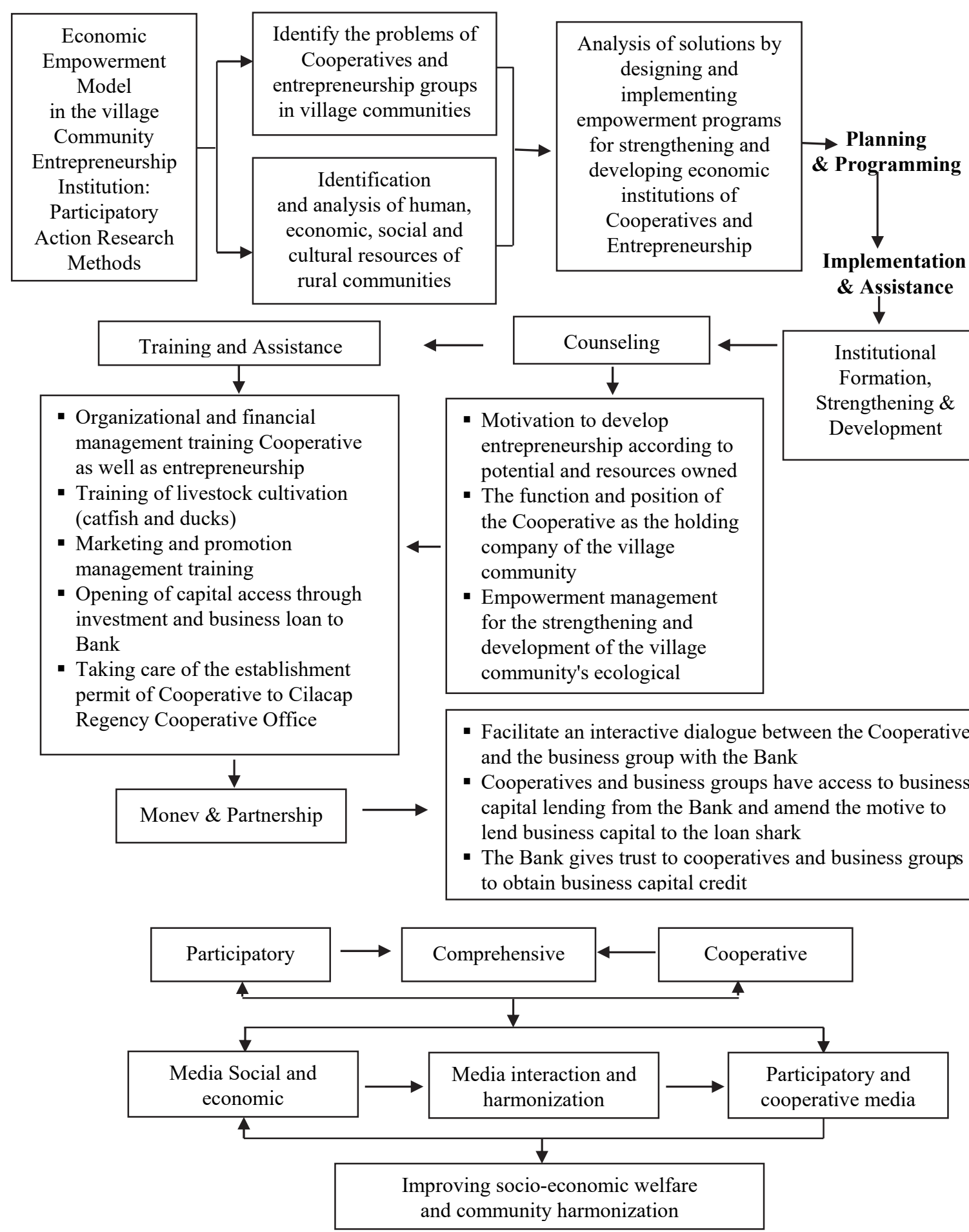

Figure 1. Economic Empowerment Model in Entrepreneurship and Cooperative Institutions

\section{Conclusion}

There is a problem of disharmony and the potential conflict in the community due to traumatic, could be anticipated by the community economic empowerment model through entrepreneurship and cooperative institutions has stages (1) The research process by conducting introducion study from literature review of research result, journal, theory and case in mass media. (2) Making economic empowerment program planning through participatory dialogue in the form of meeting with the village community to identify and analyze problems, human 
resource potential, natural resources and economic, social and cultural resources of rural communities to strengthen the economic empowerment program through discussions with stakeholders, practitioners and activists of entrepreneurship and cooperative economic empowerment. (3) Conducting economic empowerment programs through counseling, training and comparative studies on the establishment and development of entrepreneurship groups and cooperatives. (4) Conducting monitoring and evaluation of economic empowerment program with mentoring activities, observation to business location and cooperatives, participatory dialogue with entrepreneur and cooperative actors, expanding marketing access and establishing partnerships.

The model of community economic empowerment in entrepreneurship institution can be successfully implemented such as: (1) growing the spirit and togetherness in improving knowledge and skill about entrepreneurship and Cooperative, (2) Becoming process of mental rehabilitation, social and economics of society from traumatic, negative stigma and disharmony in society post-arrest incidents of suspected terrorism. (3) Developing entrepreneurship into several institutional groups such as farmer group, and craftsmen group, then Cooperative has developed into Farmer Cooperative that fulfill agriculture needs of rural community and become an officially registered legal entity and incorporated. (4) Establishing partnership access either with private parties or the Bank and local government to obtain business capital credit for entrepreneurship and Cooperatives.

The community economic empowerment model in improving entrepreneurship and cooperative needs to be carried out continuously by following up research, becoming a guided village for the implementation of community service program, real working lecture activity and student practicum.

The village government can pay more attention to the development of cooperatives and entrepreneurship groups that are owned by the community to create business fields especially for the young generation as not to leave the village by providing financial assistance, facilitating economic empowerment program, assistance and partnership and capital either with private, local government, other institutions.

Cooperative and entrepreneurship boards actively socialize and conduct a persuasive approach to other communities, especially the young generation to participate to become members and administrators to further improve business opportunities and welfare and independence of village communities.

The local government and people's representatives should pay more attention in the form of policy support for economic empowerment and assistance programs, capital assistance and marketing access to villages with economic potential.

Model of community economic empowerment in entrepreneurship and cooperative institution based on dialogical, participatory, and sustainable can be a pilot and pioneer for economic empowerment process in other area society.

\section{Acknowledgments}

We are very grateful and say thank for your attention, support and policy to Institute for Research and Community Service in University of Jenderal Soedirman who has provided his research program and The Humanities and Social Science Research who published the results of this study. We would also to thank you the informants at the research location, the Islamic boarding school, the village government and our research partners, who have supported the research process.

\section{References}

Adi, I. R. (2013). Intervensi Komunitas dan Pengembangan Masyarakat: sebagai Upaya Pemberdayaan Masyarakat. Jakarta: Rajawali Pers.

Ardiana, I. D. K. R., Brahmayanti, I. A., \& Subaedi (2010). Kompetensi SDM UKM dan Pengaruhnya Terhadap Kinerja UKM di Surabaya. Jurnal Manajemen dan Kewirausahaan, 12(1), 42-55. https://doi.org/10.9744/jmk.12.1.pp.\%2042-55

Azis, B. (2017). Kearifan Lokal Masyarakat Kampung Wisata Kerajinan Tangan di Dusun Rejoso Kota Batu. Local Wisdom, 9(1),1-11. https://doi.org/10.26905/lw.v9i1.1862

Christens, B. D. (2012). Targeting empowerment in community development: a community psychology approach to enhancing local power and well-being. Community Development Journal, 47(4), 538-554. https://doi.org/10.1093/cdj/bss031

Gemina, D., Samsuri., \& Kusuma, I. C. (2013). Keunggulan Bersaing Koperasi Berkaitan dengan Penerapan Intellectual Capital, Manajemen Keanggotaan, dan Partisipasi Anggota. Jurnal Manajemen Kewirausahaan, 15(2), 191-2014. https://doi.org/10.9744/jmk.15.2.191-204

Gruidla, J., \& Husteddeb, J. (2015). Towards a robust democracy: the core competencies critical to community 
developers. Community Development, 46(3), 279-293. https://doi.org/10.1080/15575330.2015.1028082

Harun, R., \& Ardianto, E. (2011). Komunikasi Pembangunan dan Perubahan Sosial: Perspektif Dominan, Kajian Ulang dan Teori Kritis. Jakarta: Rajawali Pers.

Handoko, W., Sulaiman, A. I., \& Akbar, A. A. S. (2014). Komunikasi Partisipatif dalam Proses Pembagunan Bendungan Matenggeng Kabupaten Cilacap Jawa Tengah. Jurnal Penelitian Komunikasi, 17(2), 141-152. https://doi.org /10.20422/jpk.v17i2.13

Hasim, \& Remiswal (2009). Community Development Berbasis Ekosistem: Sebuah Alternatif Pengembangan Masyarakat. Jakarta: Diadit Media.

Hilman, A. Y., \& Nimasari, E. P. (2018). Model Program Pemberdayaan Masyarakat Desa Berbasis Komunitas. Jurnal Aristo (Sosial, Politik, Humaniora), 6(1), 45-67. https://doi.org/10.24269/ars.v6i1.778

Hubeis, A.V. (2010). Pemberdayaan Perempuan dari Masa ke Masa. Bogor: IPB Press.

Huda, M., Mulyadi, D., Hananto, A. L., Nor Muhamad, N. H., Mat Teh, K. S., \& Don, A. G. (2018). Empowering corporate social responsibility (CSR): insights from service learning. Social Responsibility Journal, 14(4), 875-894. https://doi.org/10.1108/SRJ-04-2017-0078

Khairunnisa., Saleh, A., \& Anwas, O. M. (2019). Penguatan Kelembagaan Petani Padi dalam Pengambilan Keputusan Adopsi Teknologi IPB Prima. Jurnal Penyuluhan, 15(1), 89-96, https://doi.org/10.25015/penyuluhan.v15i1.23460

Mardikanto, T. (2010). Konsep-Konsep Pemberdayaan Masyarakat :Acuan Bagi Aparat Birokrasi, Akademisi, Praktisi dan Minat/Permerhati Pemberdayaan Masyarakat, Surakarta: UNS Press

Mardikanto, T., \& Soebiato, P. (2012). Pemberdayaan Masyarakat dalam Perspektif Kebijakan Publik. Bandung: Alfabeta.

McIntyre, A. (2008). Participatory Action Research. Hellenic College, Maryland US: SAGE Publications.

Mikkelsen, B. (2011). Metode Penelitian Partisipatoris dan Upaya Pemberdayaan. Penerjemah: Matheos Nalle. Jakarta: Yayasan Pustaka Obor Indonesia.

Nurcholis, H., Milwan, T., \& Warsono, H. (2009). Perencanaan Partisipatif Pemerintah Daerah. Jakarta: Grasindo.

Nurbudiyani, I. (2013). Model Pembelajaran Kewirausahaan dengan Media Koperasi Sekolah di SMK Kelompok Bisnis dan Manajemen. Jurnal Pendidikan Vokasi, 3(1), 53-67. https://doi.org/10.21831/jpv.v3i1.1577

Pama, P. G., \& Ganesha. (2014). Pengembangan Model Penguatan Lembaga Pertanian sebagai Prime Mover Pembangunan Kawasan Daerah Penyangga Pembangunan (DPP) Destinasi Wisata Kintamani Bali. Jurnal Ilmu Sosial dan Humaniora, 3(1), 380-393. http://dx.doi.org/10.23887/jish-undiksha.v3i1.2928

Popple, K., \& Quinney, A. (2002). Theory and Practice of Community Development: A Case Study from The United Kingdom. Journal of the Community Development Society, 33(1), 71-85. https://doi.org/10.1080/15575330209490143

Pranoto, A. R., \& Yusuf, D. (2014). Program CSR Berbasis Pemberdayaan Masyarakat Menuju Kemandirian Ekonomi Pasca Tambang di Desa Sarijaya. Jurnal Ilmu Sosial dan Ilmu Politik, 18(1), 39-50, https://doi.org/10.22146/jsp.13094

Rangkuti, P. A. (2011). Komunikasi Pembangunan dan Mekanisasi Pertanian. Bogor: IPB Press.

Reason, P., \& Bradbury, H. (ed). (2008). The Sage Handbook of Action Research: Participative Inquiry and Practice. California: Sage Publications.

Riosa, M., \& Lachapelle, P. (2015). Community development and democratic practice: pas de deux ordistinct and different? Community Development, 46(3), 190-197. https://doi.org/10.1080/15575330.2015.1032050

Rodiah, I., Putri, M. R., \& Irianto, J. (2018). Community empowerment through CSR in Public-Private Partnership Perspective in Pasuruan. Proceedings of the 1st International Conference on Intellectuals' Global Responsibility (ICIGR 2017), 125, 286-289. https://doi.org/10.2991/icigr-17.2018.69

Sahakian, M. D., \& Dunan, C. (2014). The social and solidarity economy towards greater 'sustainability': learning across contexts and cultures, from Geneva to Manila. Community Development Journal, 50(3), 403-417. https://doi.org/10.1093/cdj/bsu054 
Soegiono, L., Atahau, A. D. H., \& Huruta, A. D. (2019). Local wisdom in rural microfinance: a descriptive study on villagers of East Sumba. Entrepreneurship and Sustainability Issues, 6(3), 1485-1496. https://doi.org/10.9770/jesi.2019.6.3(30)

Sulaiman, A. I., Lubis, J., Susanto, D., \& Purnaningsih, N. (2016a). Karakteristik, Aspirasi, dan Media Informasi dalam Musrenbang Desa/Kelurahan di Kota Banjar Jawa Barat. Jurnal Penelitian Komunikasi, 19(1), 69-82. https://doi.org/10.20422/jpk.v19i1.54

Sulaiman, A. I., Sugito, T., \& Sabiq, A. (2016b). Komunikasi Pembangunan Partisipatif untuk Pembeerdayaan Buruh Mingran. Jurnal Ilmu Komunikasi, 13(2), 233-252. https://doi.org/10.24002/jik.v13i2.734

Sulistiono, Setiabudi, F., Herawati, D., Purnono, J., Sehabudin, U., Nugroho, T., \& Handayani, R. (2018). Coastal Community Empowerment Management of Anchovy (Stolephorus Spp) Fishery in Saramaake, North Moluccas Province, Indonesia: Need Assessment, Program and Evaluation. Journal of Community Development Research, 11(3), 39-55. https://doi.org/10.14456/jcdr-hs.2018.8

Tattersall, A. (2015). The global spread of community organizing: how 'Alinsky-style' community organizing travelled to Australia and what we learnt? Community Development Journal, 50(3), 380-396. https://doi.org/10.1093/cdj/bsv018

Vitasurya, V. R. (2016). Local Wisdom for Sustainable Development of Rural Tourism, Case on Kalibiru and Lopati Village, Province of Daerah Istimewa Yogyakarta. Procedia - Social and Behavioral Sciences, 216(6), 97-108. https://doi.org/10.1016/j.sbspro.2015.12.014

Wibowo, G. A. (2014). Evaluasi Pengelolaan Alokasi Dana Desa UntukPembangunan Sarana Prasarana Desa (Desa Wonoasri Kecamatan Grogol Kabupaten Kediri). Journal Pembangunan Wilayah dan Kota, 13(2), 313-325. https://doi.org/10.14710/mkmi.\%v.\%i.1-19

Windiasih, R., \& Soetiarto, N. A. (2002). Kajian pembinaan narapidana dengan sistem pemasyarakatan dalam perspektif ketahanan nasional: STudi di Lembaga Pemasyarakatan Purwokerto. Tesis. Universitas Gadjahmada.

\section{Copyrights}

Copyright for this article is retained by the author(s), with first publication rights granted to the journal.

This is an open-access article distributed under the terms and conditions of the Creative Commons Attribution license (http://creativecommons.org/licenses/by/4.0/). 